\title{
THE USE OF SMART TECHNOLOGIES WITHIN THE CONDITIONS OF DUAL EDUCATION SYSTEM
}

\author{
Mykyta Sapogov \\ Postgraduate Student, Head of the Laboratory of Innovative and Informative Technologies \\ in Education, Vinnytsia Mykhailo Kotsiubynskyi State Pedagogical University, Ukraine \\ e-mail: sopogov@ukr.net, orcid.org/0000-0002-0046-7650
}

\section{Summary}

The article reviews dual learning as a form of educational process organization, which provides a systemic and organic combination of two main components: theoretical (educational) component provided by the institution, and applied (practical) provided by the enterprise (potential employer). It is emphasized that the peculiarities of professional training of future specialists in the dual form of study include the creation of innovative educational and production environment of vocational education. An influential factor in the formation of necessary innovative environment are smart technologies that promote the organization of independent cognitive, research, project activities of students; implementation of educational process in a distributed learning environment; interaction of students with the professional community; individualization of learning process, etc. Greater focus is placed on the fact that smart technologies in education contribute to comprehensive multilevel problem solving, critical thinking, creativity in a broad sense, ability to manage people, interaction with people, emotional intelligence, self-opinion and decision making, customer orientation, negotiation skills, intellectual flexibility.

Keywords: dual form of study; models of dual education; professional training; innovative educational and production environment; smart education.

DOI: https://doi.org/10.23856/3826

\section{Introduction}

Modern trends of rapid change in technological level require the training of specialists able to daily updating of theoretical knowledge and practical skills, to possible and repeated changes in the direction of their application and even profession. Lifelong learning is no longer a competitive advantage, but a necessity related to life dynamic. The term "lifelong learning" is defined in European Commission documents as "all lifelong learning activities aimed at improving knowledge, skills and competences in perspectives of personal, civic and social development, as well as / or getting a job", and the concept of lifelong learning provides for a person's possibility to obtain necessary information throughout life to support their active life and self-realization (Commission of the European Communities, 2001). Education is constantly improving, implementing new concepts, approaches and techniques of teaching. Traditional methods are becoming less effective as they cannot be applied to new generation training. A dual system of education is widespread in European countries, that is a reasonable balance of theory and practice while studying at a university or college. Mastering the gap between education and production, as well as improving the quality of training, including employers' requirements in the framework of new organizationally different forms of education - is the main task of introducing a dual form of education (Osipchuk, 2019).

In Ukraine, the preparation process for the implementation of dual method of education began with the approval of the Concept of training specialists in the dual form of education on 
September 19, 2018 by the Cabinet of Ministers. The concept of dual education, stages of its implementation in Ukraine, basic rights and responsibilities of educational institutions and enterprises are defined in it. On April 3, 2019, the CMU approved the Activity Plan for implementation of Concept of training specialists in the dual form of education, which provides specific tasks for regulations development, analytical and organizational measures to implement the dual form of education in educational process. For the Activity Plan implementation, the Regulation on the dual form of vocational education was approved, which defines the grounds, conditions and procedure for obtaining such education in dual form in vocational education institutions. Today, the dual form of education is just beginning to be introduced into Ukrainian educational process. It is designed to establish effective cooperation of educational institutions with the labour market and create a real opportunity for market professionals to influence the content of educational curricula. At the same time, the dual form of education should not be absolute, and decision on its implementation and the choice of specialties, training of which will be carried out in the dual form, should be made considering employers' requirements and national economy and legislation features.

The purpose of the study - is to highlight the aspects of smart technologies use in the context of dual education in higher education institutions of Ukraine.

\section{Research tasks}

1. Studying scientific views of domestic scientists on the introduction of dual education in higher education institutions of Ukraine.

2. Generalization ideas of scientists and professionals activity results study for the use of smart technologies within the conditions of dual education.

The introduction of elements of dual system of education in Ukraine is carried out in accordance with such regulations as the Law of Ukraine "On Education"; Medium-term plan of the government priority actions for the period of 2017-2020, section III "Human capital development", subsection 8: "Modernization of vocational education"; Order of the Ministry of Education and Science of Ukraine dated 16.03.2015 № 298 “On the introduction of elements of dual system of education in training of skilled labour"; The Concept of Dual Education was approved by the Cabinet of Ministers of Ukraine, which aims to combine study and work to acquire a certain qualification. This concept (Concept, 2018) allows the employer to be involved in the process of training students, rather than retraining them in the production environment, as well as to use partial and financial resources of students, institutions, employers. Training in this form is based on the agreement between the employer, the institution of higher education and the student, it will give the opportunity to get education, gain certain skills, get acquainted with the production, learn to work on modern equipment using the latest technologies (Korkuna et al., 2018: 90).

The term "dual system" was introduced into pedagogical terminology in the mid-60s in Germany as a new, more flexible form of vocational training. In other words, it is a dual type of education in which the training of individuals in educational institutions takes place in enterprises. Duality as a methodological standard of vocational education includes a coordinated interaction of educational and industrial spheres for training qualified personnel of a certain specialization within the organizationally different forms of education (Dual Education, 2018).

Dual education is actively practiced in many European countries. It has given new impetus to the development of East Asian countries such as South Korea and China. Nowadays, some educational institutions, enterprises and organizations in Ukraine are ready to introduce a dual system of education. Elements of such education are already used in a number of domestic institutions of higher education - Sumy State University, Sumy National Agrarian University, 
National Forest Engineering University, Donbas National Academy of Civil Construction and Architecture, National Aerospace University named after M. E. Zhukovskyi, National Mining University and others. In these universities, students acquire knowledge not only in educational institution, but also in a real production setting. Due to this, graduates are guaranteed to get a job to which they are almost completely adapted.

The concept of dual education involves three stages of its implementation. At the first stage it is necessary to develop the legal framework for dual form introduction. The second stage is standard models development of dual education jointly by educational institutions and employers. At the third stage - the creation of dual education clusters on the basis of competitive educational institutions. There are some domestic examples of introduction of a dual form of education. It is referred to the experience of introducing dual education at the Robert Elworthy Institute of Economics and Technology (Kropyvnytskyi, Rector Vasylenko). Thus, the dual form of teaching bachelors in economics is a training focused on practical component. The purpose of introducing a dual form of education at Robert Elworthy Institute of Economics and Technology is to overcome the mismatch between the provision of educational services by higher education institutions and employers' inquiries about the structure of educational process, content and scope of curricula and programs providing the opportunity to respond quickly to changes in business technology and the ability to update the content of higher education, taking into account the requirements of specific enterprises. The choice of such trends is largely determined by presence of a wide range of potential partner companies engaged in jointly with higher education institutions in order to provide a fundamentally new system of training. Of course, the dual form of education is not suitable for every student, as it requires much more effort and self-organization (Osypchuk, 2019).

\section{Research methodology}

The following groups of research methods are used in the study: observation - a systematic purposeful study of the object with a specific purpose; comparison - finding out the differences or similarities, finding common ground for two or more objects; methods used at empiric and theoretical levels of research, in particular: abstraction - selection (identification or isolation) of essential features, properties of the subject in order to highlight certain aspects; analysis and synthesis - division of the whole into components and the study of subject in consistency, unity and relationship of its parts; induction and deduction - the conversion from individual to general in the process of formulating conclusions about features of the subject in general and introducing general provisions in the analysis of individual; modeling - the use of systems that replace the cognitive object and are a source of information about it; application of the system (model) are similar to studied objects with a high level of resemblance and insignificant differences; a systematic approach, which oriented to study the relationship of individual aspects, parties or parts as a whole and their interactions.

These methods play a leading role in research, based on theoretical foundations and data obtained on the studied problem, determine the way of further research.

\section{The main text}

The peculiarities of professional training of future specialists in the dual form of education include the creation of innovative educational and production environment of vocational education institution. Innovative educational and production environment is a set of pedagogical, 
organizational and managerial, program-methodical, material and technical, information conditions and corresponding resources of educational institutions and enterprises, which provide high quality training of competitive qualified specialists for innovative development of the country's economy. Goal-oriented design of educational and production environment of educational institutions under the dual form is carried out in order to ensure compliance with the content of education, defined by state standards, the requirements of modern production, innovative technological processes and technical support. Creating this environment is possible under the condition of developing a system of training qualified specialists on the basis of partnership between enterprises-customers of specialists and educational institutions. The educational environment was studied by both foreign (J. Gibson, W. Mace, T. Meng, M. Turvey, V. Yasvin and others) and domestic (G. Ball, I. Bekh, E. Bondarevska, S. Maksymova, O. Pekhota, V. Rybalka, V. Semychenko, V. Serikov, S. Sysoeva and others) researchers. The approach of $\mathrm{V}$. Yasvin is considered to be appropriate, as he understood the educational environment as a characteristic of life within the educational institution, the system of influences and conditions of personality formation, as well as the system of opportunities for personal development contained in social and spatial environment (Herliand et al., 2019: 88).

The main task of introducing elements of dual form of education is to eliminate the major disadvantages of traditional forms and methods of training future professionals, to bridge the gap between theory and practice, education and production, and improve the quality of training considering the requirements of employers (Khakhula, 2019: 4).

Scientists note that dual learning is a form of organization of educational process, which involves a systematic and organic combination of its two main components: theoretical (educational) component, which provides the institution, and applied (practical), which is provided by the enterprise (potential employer) (Dernova, 2014: 139). In other words, dual learning (in Germ. Duales Studium) is a system of vocational training, in which students receive theoretical knowledge in educational institution and professional skills in the company of the employer simultaneously (Drazhnytsia, 2016: 17). The dual form of education involves the combination of theoretical training with practical - in the workplace in order to acquire appropriate professional qualifications. This is the duality - the obligatory supplementation and improvement of acquired theoretical knowledge by practical experience. While implementing this form of education, the educational institution and the employer are equal partners, as the latter can participate in the development of working curriculum and individual education plan and evaluate the results of each student. The interest in such cooperation is to receive a young highly qualified employee who is highly motivated to work at the company immediately after graduation.

Organizing educational process according to new, productive educational technologies includes: introduction of innovative technologies that have a high potential for viability; providing the educational process with information sources; the presence of the enterprise of the customer, as a social partner, with a high organization of production process, provided with the latest production technologies and equipment and skilled labour resources; creation of innovative climate among teachers, their active involvement in innovative tasks implementation and their high professionally qualified level and creativity; introduction of advanced educational technologies; requirement for skilled workers of certain professions and the prospect of further graduates' employment.

The dual form of education offered by the Ministry of Education and Science provides for a combination of higher education and on-the-job training. Lectures are held in lecture halls, and practical and laboratory, as well as course projects - in the company. Such a student-worker fully performs his duties, receives a scholarship roughly the same as the salary. It is important 
not to confuse the experience of students who combine work and study with dual education. According to this, the student misses classes, which then have to be made up, and also risks of being left without a diploma. In universities a large amount of work placement is often referred to as a dual form of education. In fact, in dual programs, a student spends about the same amount of time in the workplace as in an educational institution.

For a proper practical training in the workplace, according to scientists, it is necessary to develop a practical training program for each discipline, which should reflect: purpose, objectives, templates (tables, formulas, graphs, etc.), recommendations for conclusions, list of recommended sources and assessment criteria of knowledge, skills and practical abilities acquired during the practical training. (Khakhula, 2019: 25).

Although it is believed that dual education is best suited for training in technical specialties, the German experience shows the range of applications of this model is much wider. Thus, in Germany the list of programs that include dual training includes: finance, manufacturing, trade, services, transport and logistics, tourism, international business administration, business informatics, IT, construction, electrical engineering, mechanical engineering etc (Romaniuk, 2019).

In scientific discourse it is generally accepted that the dual study - is a means of obtaining vocational education, which involves combining the training of individuals in educational institutions with training in the workplace at enterprises, institutions and organizations to obtain appropriate qualifications on the basis of a contract for vocational education in dual form.

The task of dual study is to ensure that the quality of vocational education meets the requirements of the labour market. The dual study of vocational education is based on the fulltime form of vocational education and can be combined with other types of institutional forms of vocational education (Regulations, 2019).

The introduction of dual system of higher education should ensure:

1) balance between supply and demand of specialists in the labour market;

2) participation of professional communities and business in formation of educational programs, professional standards and educational process organization;

3) formation of a new generation of curricula, in which, in addition to the theoretical component, practical training in the workplace will occupy an important place;

4) convergence of two structures - education system and employment system, ensuring a balance of interests between employers' demands and educational institutions' supply;

5 ) increasing the share of employment of graduates of higher educational institutions;

6) along with the professional qualifications of young professionals, their acquisition of social and communicative competencies;

7) an opportunity for the employer to choose the best specialists for work;

8) financial confidence of the student during his studies, employment guarantees and future professional career;

9) improving the image of the university among applicants and employers, qualitative and motivated student body and their successful employment, the prospect of obtaining new technologies and teachers' upgrade training, additional funding, improving facilities and closer integration of education, science and business (Khakhula, 2019: 4).

The main principles of dual education system: the university / college and the enterprise take part in educational process; ratio 30/70\%: studying is based on the principle of " $30 / 70 "$, where $30 \%$ is theory studying, and $70 \%$ - practice; correct motivation; sufficient funding for training; course projects and diploma papers are real researches that the enterprise requires. 
The concept of "Modern vocational education" states that modern educational environment is a material and technological, social and physical-spatial environment (accessible, innovative, business-oriented, open, inclusive, value-oriented, developmental, motivating), programs, technologies and teaching aids, smart design, which contribute to the acquisition of personal competencies of professional education throughout life. It should provide a transition to the systematic introduction of IT in all types of educational activities, the creation of online platforms with educational and methodological materials for students and teachers, the use of electronic textbooks, content libraries, smart systems, new IT technologies, multimedia training, social professional networks. High-tech educational and practical centers and laboratories are being created, startups, simulation centers, educational and production clusters, and business incubators are being launched in educational process. All these conditions ensure the commonality of educational content and the content of production, as the source of formation of the content of professional (vocational) education are technological processes, equipment and production techniques (Herliand et al., 2019: 90). In general, the creation of innovative educational and production environment of educational institution under the conditions of dual system of education makes it possible to ensure the modern quality of training and retraining of workers and specialists for primary industries with the involvement of social partners; to achieve correspondence between educational and professional interests of the person, labor market demands and the number of trained experts of declared specializations; to regain prestige of working professions and recognize the values of practice-oriented education (Herliand et al., 2019: 92).

In today's evolving development of technology, a constant educational trend is smart education, the concept of which provides a significant number of sources, maximum diversity of multimedia, the ability to quickly and easily adjust to the level and needs of students (Tykhomirov, 2011: 22). Researchers of smart education call its basic principles the use of relevant information of the curriculum to solve educational problems; organization of independent cognitive, research, project activities of students; implementation of educational process in a distributed learning environment; interaction of students with the professional community; individualization of training; providing a wide range of opportunities for all who wish to learn (Gurevych, Kademiia, 2016: 71). The most accurate illustration of smart education is on-line courses or their platforms, for example, Prometheus - Ukrainian public project of mass open on-line courses, the main purpose of which is to provide free access to university-level courses to anyone regardless of residence, age, wealth and health (Best education for everyone, 2020). Prometheus contains both a domestic educational product and Ukrainian-translated courses for foreign universities or educators. In particular, domestic courses are not always adapted to the on-line listener, tend to a more static academic teaching style with no dynamic content, partly only by one author, have relatively long video lectures with many irrelevant examples concerning life, jokes, inaccurate narrations of historical facts.

As for the assessment of learning outcomes, used tests also differ significantly: domestic formulations are aimed at accurate memorizing, rather than obtaining general essential knowledge, and tests themselves contain a large number of complex questions. When focusing on the formation of skills as a competence of a modern specialist, "hard skills" as professional knowledge, skills and abilities necessary for successful work in specialty, can not always be formed on-line, especially, due to regulation of certain activities and absence of strict verification of on-line tests listener when passing the test for a certificate. But "soft skills" necessary for self-development can be formed in such a dynamic mode of smart education. Such skills include Complex problem solving, Critical thinking, Creativity in a broad sense, People management, Coordinating with others, Emotional intelligence Judgment and decision-making, 
Service orientation, Negotiation, Cognitive flexibility (Job of the future: 10 skills in demand in 2020). If not to master, then to update these skills is not only real, but also necessary with the help of on-line education. Thus, lifelong learning, duality, smart education, formation of soft skills with the help of on-line courses can be highlighted as modern educational trends. Online courses, digital resources, services and applications, on-line conferences, webinars and personal virtual lessons in real time - these are not complete tools of virtual E-Learning education. Today, researchers are talking about a new profession - the curator of the online platform.

He designs online courses for distance learning, adapting the requirements of specific disciplines to online environment, administers the work of platform, solves communication problems between teachers and students; can help form search criteria, where and how to search information, how to evaluate and interpret it; forms critical and logical thinking, helps to separate important from unimportant, explains which resources can be trusted and which cannot, teaches media literacy and network security (Professions development forecasts in education, 2020). Information technologies in higher education institutions should be used in the territory of institution, in dormitories, because their mission is to help in scientific research, during teaching, communication, management. Open Course Ware project is successfully operating in European universities, with the help of which there is open access to the material of lectures, seminars, laboratory works online on the university website. In some institutions of higher education, for example, video lectures are popularized. Students receive handouts for a week or homework if they do not have time or miss. Such lecture is always finished, and the next one begins with a reminder of questions; there is a control system, plan, links to other materials. The student's electronic workbook is positively evaluated, where the lecture is given in short-hand form. Cloud technologies are successfully used, where the teacher places a methodical complex to his disciplines. The folders "Teacher's Cabinet", "Student's Cabinet", "Curricula", "Student's Works" are created (the student has access, can get methodical material for reading, can see his grades), "Group list", "Miscellaneous" (instructions, schemes, the plan for each group), Sugar Sine - the system which carries out the admission through the messenger and its degree (office hours, monographs, announcements, control works, educational and professional programs). The programs are not very difficult, so both the teacher and the student are able to collaborate and gain experience of Internet opportunities.

SMART-technologies are widely implemented and applied in pedagogical practice in the context of STEM-education. The modern teacher faces important tasks that must be solved to make the learning process interesting, creative and such that to meet all the needs of the modern student and intensify cognitive and exploratory activities in teaching physics. Due to this, there are changes in the process of teaching physics and technical disciplines in higher education with the use of modern information technology. Personal computers, SMART boards and Internet are essential tools in learning process. In addition, the use of SMART technologies in learning process allows you to more widely and fully reveal the creative potential of each student (Halishnikova, 2007: 8). Thus, it becomes clear the relevance of SMART technology use in educational process: students perceive information faster, participate in group discussions, work together, pass individual tests; effective feedback is established in the "student-teacher" system (Rostoka, 2019: 81).

\section{Conclusions}

Thus, the dual form of vocational education is based on full-time form and can be combined with other types of institutional forms of vocational education. Among modern forms that effectively influence the educational process are smart technologies. Smart technologies 
in education contribute to complex multilevel problem solving, critical thinking, creativity in a broad sense, the ability to manage people, interact with people, emotional intelligence, own opinion and decisions formation, customer orientation, negotiation skills, intellectual flexibility.

\section{References}

Halishnikova Ye. Vykorystannia interaktyvnoi Smart-doshky v protsesi navchannia [Using an interactive Smart-board in the learning process] Uchytel. 2007. № 4. S. 8-10 [in Ukrainian]. Hurevych R., Kademiia M. Smart-osvita - nova paradyhma suchasnoi systemy osvity. Teoriia $i$ praktyka upravlinnia sotsialnymy systemamy [Smart education is a new paradigm of the modern education system. Theory and practice of social systems management] 2016. № 4. S. 71-78. [in Ukrainian].

Dernova M. H. Dualna model vyshchoi profesiinoi osvity doroslykh: Yevropeiskyi dosvid [Dual model of higher professional education of adults: European experience] [Elektronnyi resurs] / M. H. Dernova // Osvita doroslykh: teoriia, dosvid, perspektyvy. Vypusk 2 (9) 2014. Rezhym dostupu : http://irbis-nbuv.gov.ua/cgi-bin/irbis_nbuv/cgiirbis_64.exe?C21COM=2\&I21DB$N=U J R N \& P 21 D B N=U J R N \& I M A G E \_F I L E \_D O W N L O A D=1 \& I m a g e$ file_name $=P D F /$ OD_2014_2_19.pdf, s. 139. [in Ukrainiān].

Drazhnytsia S. A. Drazhnytsia O. M. Dualne navchannia, yak interaktyvna forma orhanizatsiyi navchalnoho protsesu [Dual learning as an interactive form of the educational process organization] Zbirnyk naukovykh prats Khmelnytskoho instytutu sotsialnykh tekhnolohii Universytetu "Ukraina», № 12/2016. S. 17-20. [in Ukrainian].

Dualna osvita [Dual education] Ministerstvo osvity i nauky Ukrainy: ofitsiinyi sait. 2018. URL : https://mon.gov.ua/ua/osvita/profesijno-tehnichnaosvita/dualna-osvita [in Ukrainian].

Dualnaia systema obrazovaniia: o pryntsypakh y vozmozhnostiakh realizatsii v Ukraine [Dual educational system: about the principles and opportunities for implementation in Ukraine] URL: https://buki.com.ua/ru/news/dualna-systema-osvity-pro-pryntsypy-i-mozhlyvosti-realizatsiyi-v-ukrayini / [in Ukrainian].

Kontseptsiia pidhotovky fakhivtsiv $u$ vyshchii osviti za dualnoiu systemoiu: pryiniata 19.09.2018 $r$. [The concept of specialists' training in higher educational establishments according to the dual system: adopted on September 19, 2018$]$ Kabinet Ministriv Ukrainy: ofitsiinyi sait. URL : https://www.kmu.gov.ua/ua/news/koncepciya-pidgotovkifahivciv-za-dualnoyu-formoyu-zdobuttya-osviti [in Ukrainian].

Korkuna O. I., Korkuna I. I., Tsilnyk O. Ya. Suchasni protsesy rozvytku dualnoyi osvity: zaporuka stabilnosti kadrovoho potentsialu. Sotsialno-ekonomichni problemy suchasnoho periodu Ukrainy [Modern processes of the dual education development: a guarantee of personnel potential stability. Socio-economic problems of the modern period of Ukraine] 2018 Vypusk 4 (132) S. 90-94. [in Ukrainian].

Naikrashcha osvita dlia kozhnoho [The best education for everyone]. URL: https:// prometheus.org.ua [in Ukrainian].

Orhanizatsiia dualnoi formy navchannia u zakladakh profesiinoi (profesiino-tekhnichnoyi) osvity [Dual form of education rganization in institutions of professional (vocational) education]: prakt. posib. I T. M. Herliand, I. A. Drozich, N. V. Kulalaieva, H. M. Romanova, M. M. Shymanovskyi; za zah. red. N. V. Kulalaievoi. - Zhytomyr: «Polissia», 2019. - 304 s. [in Ukrainian]. Osypchuk Nataliia Uchytysia pratsiuvaty: chomu ukrainskym VNZ potribno zaprovadzhuvaty dualnu osvitu [Learning to work: why Ukrainian universities need to introduce dual education] URL : https://www.umoloda.kiev.ua/number/3411/188/129725 [in Ukrainian]. 
Pro zatverdzhennia Polozhennia pro dualnu formu zdobuttia profesiinoyi (profesiino-tekhnichnoyi) osvity. Nakaz Ministerstva osvity i nauky Ukrainy vid 12.12.2019 № 1551 Zareiestrovano v Ministerstvi yustytsii Ukrainy 20 liutoho 2020 [The Regulations on the Dual form of obtaining professional (vocational) education approval. The Ministry of Education and Science of Ukraine Order dated 12.12.2019 № 1551 Registered in the Ministry of Justice of Ukraine on February 20, 2020 for № 193/34476r. za № 193/34476] URL : https://zakon.rada.gov.ua/laws/ show/z0193-20\#Text [in Ukrainian].

Prognozy razvitiia professii $v$ sfere obrazovaniia [Forecasts of the professions' development in the field of education] URL: https://uchportfolio.ru/blogs/read/? id=1767.

Robota maibutnoho: 10 navychok, yaki budut zatrebuvani $v 2020$ rotsi [Work of the future: 10 skills that will be in demand in 2020.] URL:https://ukr.media/science/280897/[in Ukrainian]. Romaniuk Iryna. Dualna osvita: yak tse pratsiuie? [Dual education: how does it work?] URL: https://uba.ua/ukr/news/7483/[in Ukrainian].

Tikhomyrov V. P. Mir na puti Smart Education: novye vozmozhnosti dlia razvitiia [The world on the path of Smart Education: new opportunities for development.] Otkrytoe obrazovanie. 2011. № 3. S. 22-28 [in Russian].

Khakhula V.S. Dualna forma zdobuttia vyshchoi osvity: metodolohichni pidkhody ta osoblyvosti orhanizatsii pidhotovky studentiv za spetsialnistiu - 201 «Ahronomiia» [Dual form of higher education: methodological approaches and features of the students' training organization in the specialty - 201 "Agronomy"] / V.S. Khakhula,O.S. Horodetskyi, M.B. Hrabovskyi, L.H. Yakovyshyn, L.V. Tsentylo / Za red. O.S. Horodetskoho. Bila Tserkva, 2019. 25 s. [in Ukrainian].

Commission of the European Communities. Brussels, 21.11.2001. COM (2001) 678 final. Communication from the Commission «Making a European Area of Lifelong Learning a Reality». URL : http://eur-lex.europa.eu/LexUriServ [in English]. 